\title{
AN AGRICULTURAL SECTOR MODELS FOR REGIONAL POLICY ANALYSIS AND STRATEGIC PLANNING
}

\author{
Henrikas Pranevičius ${ }^{1}$, Algimantas Kurlavičius ${ }^{2}$ \\ ${ }^{1}$ Kaunas University of Technology, Studentu g. 50, LT-3031, Kaunas \\ ${ }^{2}$ Lithuanian University of Agriculture, Studentu g. 11, LT-4324, Akademija, Kauno r. \\ ${ }^{1}$ e-mail:hepran@if.ktu.lt; ${ }^{2}$ e-mail: alkur@kaunas.omnitel.net
}

Received 28 April, 2003

\begin{abstract}
The integration of Lithuania into the European Union requires serious preparation, determining possible changes in agrarian sector and rural development and their consequences, ensuring the necessary information supply to finding and substantiation of rational strategic solutions. The paper analyzes trends of systematic analysis of the agrarian sector of the region, tools for the search of solutions, reveals the possibilities of modelling methods and information technologies application in determining the sustainable development strategy. The suggested methodic of integrated modelling of agricultural production processes in regional and farm level is introduced. The scheme of agrarian production system and some functional dependencies are presented. The problems that are expected to be solved in future are formulated.
\end{abstract}

Keywords: integrated regional modeling; agricultural sector.

\section{Introduction}

The prospective integration of Lithuania into the European Union requires serious preparation, determining possible and desirable changes in agrarian sector and rural development and their consequences, selection of effective means for the development regulation, ensuring the necessary information supply to finding and substantiation of rational strategic solutions. Regional development should be based on optimal proportion of social, natural, economical components and should be focused on the improvement of living standard and its quality. Management of the processes of changes in agrarian sector should be purposeful [1].

In West states the measures of regional economics development are directed to the development of economically weak territories [2]. In order to reduce social and economical differences among regions the problems of less favorable for farming territories should be solved. In the European Union the main measures of rural regional policy is compensation of the suffered losses to the farmers in less favorable locations of municipal level, where conditions for farming are worse than average in the country and they determine insufficient level of income [3]. Aiming to avoid migration of farmers from the unfavorable for farming regions, to preserve the existing landscapes and regional traditions of economical activity substantial compensations from the EU structural funds are paid to farmers in less favorable locations.

Representatives of regional administrative and local self-government institutions, and those preparing regional development programs should properly form and implement the regional development strategy. Sustainable regional development model should present a comprehensive evaluation of economical growth, environmental protection and social aspects. Analysis of sustainable regional development should embrace the research of natural resources exploitation dynamics, to show future consequences of present decisions, made the resource exploitation. Main branch of rural economics - agriculture should be analyzed from the standpoints of supply with food products and raw materials, and ecological balance. 
Preservation of the environment that is healthy to live in and permanent balance of ecosystem are of great importance. Many European countries develop the laws directed to the decrease of harmful influence on environment and make farmers master new production systems. Cities and villages of the region function as harmonious whole. Regional rural development and agricultural policy should be coordinated with economical and social policy of the Lithuanian republic.

Rates and efficiency of regional agrarian sector development are influenced by a great number of internal and external factors of various natures. It is important that those, who form the development strategy, understood the development tendencies, the impact of present decisions on the process of development in future. Rural development and land use monitoring, the required information provision to politicians and planners can be used in helping them to understand the development process and influence it $[4,5]$.

Search for the solutions of regional agrarian sector optimal development requires systematic analysis, which needs certain tools for its implementation. Foreign experience shows the method of modelling to be perspective for the analysis of agrarian sector development, while the models of agrarian sector appear to be a powerful tool for regional policy analysis $[6,7]$. A number of concrete quantitative and qualitative instrumental measures for regional rural development analysis has been proposed in different countries [811]. Lithuanian experience in this field is not rich and, therefore, lack of the measures that could be used in formation of regional rural development is felt at present in the country. Having supplied the regional policy makers with proper information they can be given the possibility to be at the helm of the influencing forces and development process.

This paper aims to identify the problems of systematic analysis and modelling of agrarian sector development in rural region, to evaluate the possibilities of modelling technologies application in selection of regional development strategy, to discuss the influence of modelling on the process of rural development decision making and to suggest the models, necessary for that.

\section{Systematic approach to regional agrarian sector development analysis}

Technical, natural and agrarian ecosystems constitute the regional landscape. Technical systems - result of human creativity. Natural ecosystems exist on the basis of internal balance and self-regulation. Agrarian ecosystems are created due to human activity, which always has a purpose - to produce products, to protect nature, etc. Agrarian systems as well as natural systems are fed by the sun, however, in order to ensure high productivity of these systems the removal of nutrients together with production has to be compensated and the system has to be supplemented with big amounts of energy and materials. Optimal functioning of regional agrarian ecosystem as a complex biological - social - technical system can be ensured only by systematic solution of the analyzed problems. Methods of systematic analysis and modelling are intensively applied not only in urban and industrial sectors but also in the research of rural development [12]. Systematic approach requires complex and comprehensive investigation of the analyzed object. The analyzed regional agrarian ecosystem should be analyzed as the one consisting of the components that interact among themselves and with external environment, all important internal and external relations of the components have to be evaluated. As agrarian ecosystems combine biological and physical components, the social and agricultural production aspects have to be analyzed in them. The analysis of agroecosystems unites the efforts of economists, agronomists, zootechnitians, ecology specialists, sociologists, engineers and other specialists.

The theory of systems indicates that prior to the analysis of regional system it has to be simplified, i.e. a model is needed. Modelling of the analyzed system enables to foresee the reaction of the system to the governing impacts, hindrances and at the same time reduce the uncertainties of the system behavior. The modelling approach contributes to successful combination of the experience of competent specialists and computer possibilities.

Macroscopic investigation of regional agrarian sector can be limited to its description as the object input output relations with external environment. The input - output relations are written by functional dependencies. Such approach does not evaluate inner structure of the system, and is limited to general development strategy. On the contrary, microscopic method of the system depiction is related to the evaluation of single elements and their interrelations, distributions of the elements in space and time is introduced. Every element can be described by a number of characteristics, its statical character and dynamism, activity and passivity are evaluated. Hierarchical approach requires to analyze regional system as the whole of subsystems. Analysis of the dynamics of agrarian ecosystem includes evaluation of its activity, change of characteristics, peculiarities and sequence of determining proc- 
esses and events. All the mentioned aspects supplement each other and, therefore, usually are applied together.

Management of regional agricultural production, which evaluates economical, social and ecological processes, becomes the management of agrarian ecosystems. Cybernetic essence of the process of agricultural production management and regulation lies in the following: the managing subsystem measures the variables of the managed subsystem and, in respect to the existing restrictions, selects the management impacts in such a way that agricultural system functions efficiently, although influenced by hindrances from the environment. The managing impacts change states of the system, i.e. move the system from one to other point of states space. Factual, normative and prognozed states of the system have to be evaluated. In the case of significant divergence from the desirable state observed, operative unplanned decisions have to be made. As expenditure to energy and environmental protection is constantly increasing serious efforts are needed in the field of technologies improvement. In this case experimentation often is not wanted and impossible, therefore, modelling is the most reliable way to deal with the problems faced.

At every moment of time regional agricultural system and its surrounding environment can be described referring to particular information. State of agricultural system, as well as that of any other system, at the given moment is described by the variables of the state. The variables can be grouped into external and internal ones, managed and unmanaged ones. Complexity of biological systems and great number of their parameter variations make the adequate description of real processes in regional agrarian sector more difficult. Underestimate of unique character, complexity, indetermination, instability of agriculture causes difficulties in the systematic analysis of regional agricultural development. Besides, regional policy makers face a lot of often contradicting aims, e.g. supply with ecological products, improvement of living standard, decrease of pollution, their actions are limited by resources, demand, permissible pollution standards, etc.

The process of preparation of decisions is the most complex one in agricultural management system. This process embraces analysis of the information about the course of agricultural and food products production and processing, formulation of the essence of the problem, setting restrictions, aims and measures to achieve them, creation of the model, calculations and, if needed, making decision about taking appropriate measures of influence. Decision making is facilitated by agricultural decisions support systems and expert systems.

Functioning of agricultural system has a number of different aspects, every aspect has to be modelled separately. In fact every agricultural model is aimed at the implementation of particular aims and is made for solution of certain problems.

Systematic analysis and modelling contribute to solving practical problems of natural and agricultural systems management on large scale - from region to field, to analyzing complex physical, chemical and biological processes and establishing causal relationships, to forecasting the consequences of human activity, to making reasonable decisions and economically and ecologically efficient management of production in agrarian sector.

\section{Measures of regional agrarian sector development systematic analysis}

Various models are used in the analysis of agrarian sector and agricultural development forecasting. Empiric statistical models - regression equations, made on the basis of reported data from farms of the region are often used. During statistical analysis at the beginning general analysis of the investigated object is done and then analysis of separate elements, their relations and dependencies follows. Econometric models are used in agricultural production prices forecasting [13], description of agricultural sector growth modelling, relations of production, resources and their use [14].

Algorithm models, e.g. those of the operations analysis, are applied in seeking for the best meaning of the analyzed object aim function by the method of repeated calculations, in evaluation of technical, money supply, time and other limitations. Model of mathematical programming is successfully used to improve planning of agricultural systems development [15]. The model of recursive linear programming with several agricultural products as outputs, evaluating limitations of regional resources and forecasting plantgrowing and animal husbandry income can be used for the analysis of the impact of agricultural sector development policy, including prices and subsidies [6]. The example of Turkey agricultural sector model [16] demonstrates the suitability of mathematical programming models, which can have insufficient statistical data, for agricultural sector policy analysis.

The dynamic simulation model is used in experiments with computer model of the analyzed system and in solution of the problems that cannot be analyzed in 
detail using the methods of mathematical analysis. The simulation models are less demanding for the amount of initial data, needed for aggregation, than econometric models, their solutions are stable enough. This makes them attractive for the analysis of regional development analysis. The simulation models are convenient as instruments in management of changes in agriculture as they help to investigate a wide field of agricultural policy change. Literature sources present examples of modelling, which indicate biological-economical simulation models to be good instrument for the analysis of sustainability and determining the consequences of natural resources exploitation [17]. Simulation models of field cultivation and animal husbandry technologies contribute to relatively convenient determination of output reaction to the development of events or subject, and, therefore, have become an attractive instrument in agricultural production. Simulation modelling is frequently applied in solving the problems of selecting land use methods and intensity prognosing, coordination of economical and environmental requirements, functioning of farms, agricultural works organization, agricultural machinery services provision, etc. [18, 19].

Technological and economical simulation models of agriculture can be coordinated with the methods of mathematical programming. Stochastic models are used for the probability evaluation of the influence of accidental changes of natural conditions. In the case of the problems that cannot be solved by algorithms the methods of artificial intellect, enabling to avoid the analysis of every permissible variant of solutions and to reduce the number of search variants, are applied.

The aim of cognitive models is to determine structure of the analyzed regional system and its functional dependencies that explain intersystem relations, form behavior of the system. Models of prognosing evaluate future values of the system variables and their changes with regard to the foreseen events and solutions. Project or management models are used to verify the dependence of the systems functioning peculiarities on the system parameters, initial values of the state variables, external events and the decisions made. It should be taken into consideration that single models of low level, although having strong distinctive ability (e.g. photosynthesis, plant growth, farm management, etc.), do not provide sufficient information that is needed to make systematic decisions in regional development strategy formation. Meanwhile, big and detailed regional model is not convenient for making separate operative decisions, therefore, hierarchy of models is needed.
Application of integrated modelling approach to the study of regional agrarian sector development possibilities and formation of development strategy where different level models of biological, technical and social processes are united for the common purpose. The scheme of such integrated modelling system is presented in Fig. 1.

The data accumulated in regional database shows economical situation in the region and labor employment, biological indices indicate characteristics of soils, influence of fertilizers on environment, pollution of environment, etc. Data about land users can be obtained from farm reports. The main types of farm specialization can be distinguished, farms can be grouped by the method of cluster analysis.

The modules evaluating climatic conditions, soil characteristics, processes in soil including water balance, changes of nitrogen and phosphorus contents, soil $\mathrm{pH}$, erosion are used for the simulation of biological processes in plant-growing, biomass prognosis. Agricultural and food products production simulation model, which is made of the main plant-growing and animal husbandry blocks, selects land use scenarios, forms material input flows, introduces alternative production systems, based on the investigated technologies, evaluates regional level development limitations. Results of this model are used in determining plant growing and animal husbandry production optimized linear programming model coefficients and formation of agrarian sector development strategy. Simulation model can check the stability and sensitivity of the chosen variant of development to hindrances.

Having chosen the agrarian sector development strategy farm level activity analysis can be done. Farm is the main cell of agricultural production in the region. Farm can be analyzed dynamic system, limited by certain restrictions, which uses the chosen technologies to achieve the aim. The model of linear programming, which according to the introduced data calculates what crops grown in what area and the number and breeds of animals kept in the farm give optimal income, is used to select farm specialization and to project the optimal production structure [20]. The simulation model is suitable to describe activity dynamics of a separate farm in the region. Frame model, reflecting logic structure of the farm, is used. Such model becomes functional only when completed with real farm data. The model can be used in farm decision making, projecting of farm systems or resources management, analysis of supply problems, research and training. Strong changeability of agrarian ecosystems and possible significant changes of influencing 


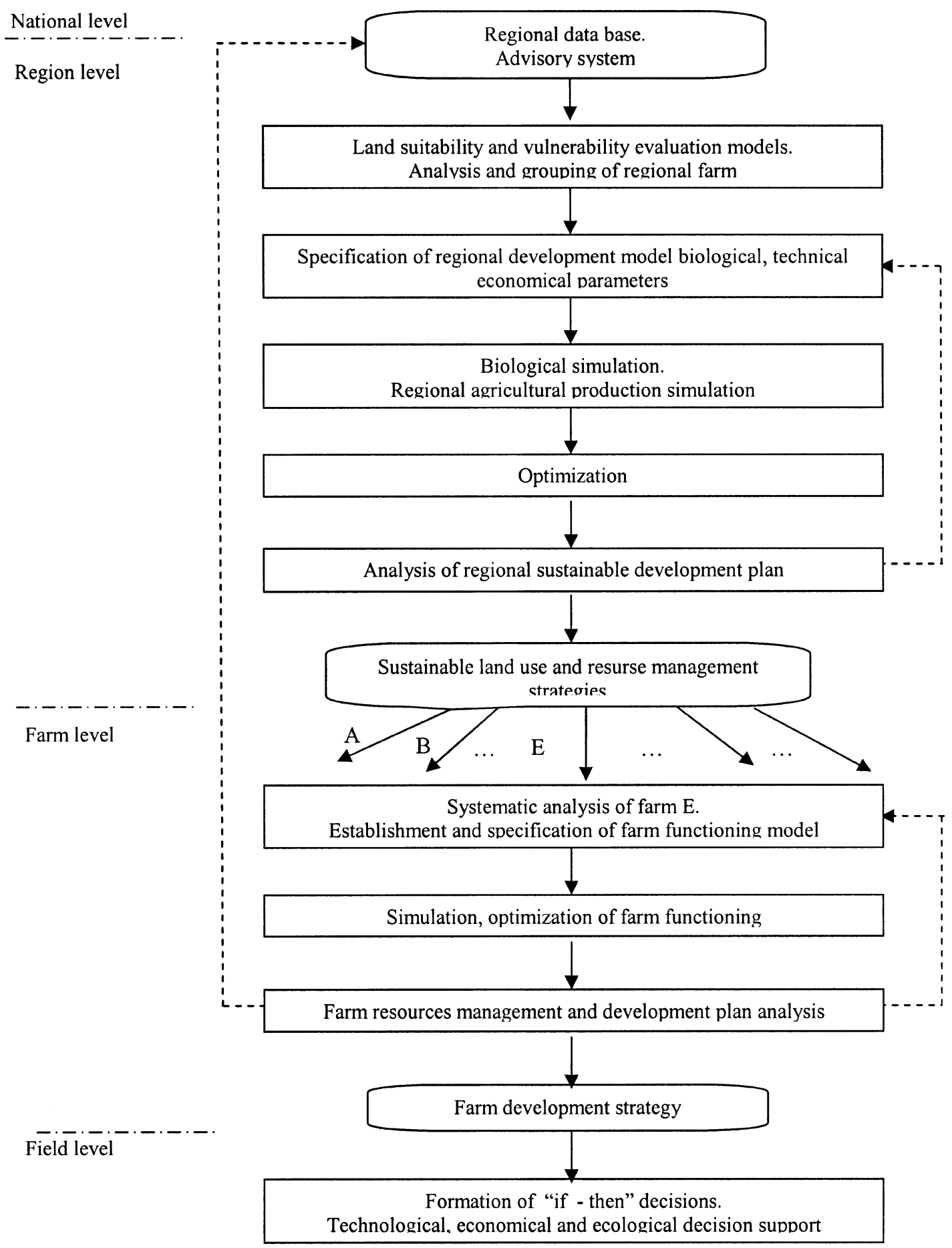

Fig. 1. Integrated modeling system for the analysis of regional agricultural sector at different hierarchical levels 
factors in space and time should be evaluated. Aggregate field level simulation model provides the possibility to analyze field activity scenarios, to verify efficiency of plant-growing technologies, to get answer to the question "If - Then" [18]. Models are interrelated, calculation results of some models are initial data for other models. Regional agricultural system is introduced into state agricultural system.

\section{Conceptual regional model of agricultural production}

In the course of agricultural production the products of agriculture are obtained. Human, material and financial resources as well as the applied technologies and infrastructure are in the basis of agricultural activity. Regional agricultural system actively interacts with environment - the flows of materials, energy and information circulate.

In the implementation of regional strategic aims the factors, influencing the entire agriculture of the country, including the policy and results of single farms activity, manifest themselves. Natural conditions, climate, soil - are the factors, to which regional agriculture has to adapt to by making use of all the provided advantages and by overcoming the dangers. The external environment that influences agriculture little depends on the will and efforts of agricultural subjects while it strongly influences their results. The influence of environmental factors can be softened or even neutralized by selecting appropriate measures of influence, branches of agriculture, which are better suited to local conditions.

Two main components can be distinguished in the model of agricultural production, that is the managed agroecosystem, presented in Fig. 2 and the system of management, which consists of people, aims, data and knowledge, monitoring possibilities and decision making. Agroecosystem as a complex system has material, energetical, information relations and connections with outside. Agroecosystems as biological-physical production systems with physical inputs and outputs in detailed model can be used in air, soil, hydrology, crop growth, feed requirement, animal, economics, output module. The model evaluates the movement of various animal breeds in different age groups, production processes bind inputs and outputs.

The connection between the production system inputs and outputs can be described by production functions. The vector $\mathbf{L}$ of plants growth limiting factors depends on the vector $\mathbf{U}$ of the managed factors (fertilization, etc.) and on the initial value $\mathbf{L}_{0}$ of the factor limiting vector (soil characteristics):

$$
\mathbf{L}=F_{1}\left(\mathbf{U}, \mathbf{L}_{0}\right) .
$$

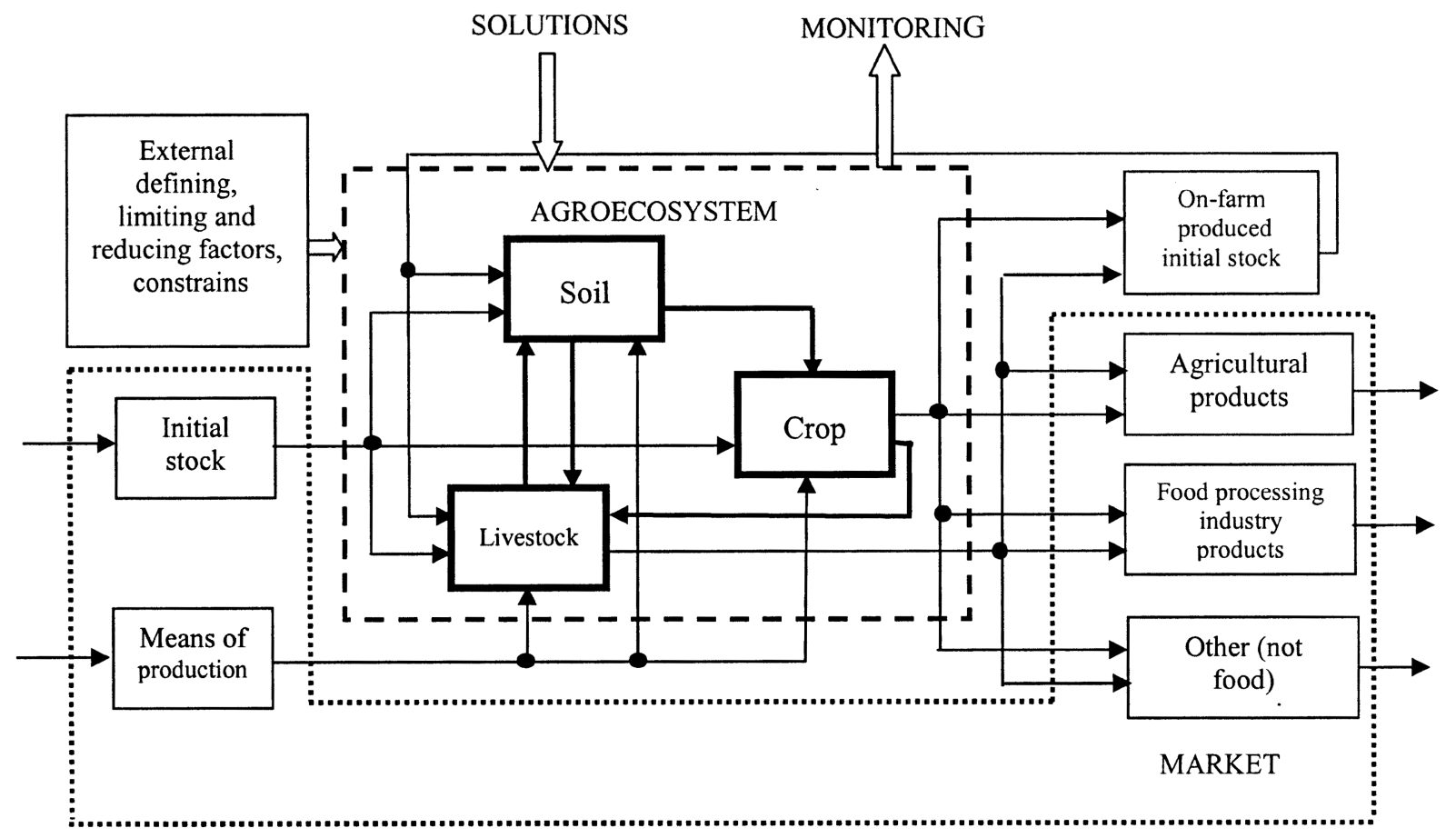

Fig. 2. Schematic representation of regional agricultural production system 
The vector $\mathbf{R}$ of plant growth reducing factors (plant diseases, number of pests) depends on the initial value of this vector $\mathbf{R}_{0}$, growth hindrances management impact $\mathbf{U}_{\mathrm{r}}$ (e.g. pest and disease control), limiting factors vector $\mathbf{L}$ :

$$
\mathbf{R}=F_{\mathrm{r}}\left(\mathbf{U}_{\mathrm{r}}, \mathbf{L}, \mathbf{R}_{0}\right)
$$

Physical environment of agroecosystem is influenced by the vector $\mathbf{D}$ of its characteristic, growth defining factors. Agricultural plant-growing system outputs $\mathbf{Y}_{\mathrm{a}}$ are function of the inputs $\mathbf{X}$, applied technologies $\mathbf{T}$ and influencing factors (for the purpose of simplification the stochastic parameter $\mathrm{x}$ is not shown):

$$
\mathbf{Y}_{\mathrm{a}}=F_{\mathrm{y}}(\mathbf{X}, \mathbf{T}, \mathbf{D}, \mathbf{L}, \mathbf{R}) .
$$

The managed impacts, limiting and determining factors, used technologies also form a useless plant-growing output $\mathbf{Z}_{\mathrm{a}}$ (pollutants, soil erosion, etc):

$$
\mathbf{Z}_{\mathrm{a}}=F_{\mathrm{Z}}\left(\mathbf{U}, \mathbf{U}_{\mathrm{r}}, \mathbf{T}, \mathbf{D}, \mathbf{L}_{0}\right) .
$$

Production functions of animal husbandry produce are written in analogous way. For economical evaluations the expressions (1)-(4) should be supplemented with profit function. For this purpose the outputs and inputs have to be bound with prices and existing limitations of corresponding resources (land, labor, equipment and machinery):

$$
\mathbf{P}=c_{\mathrm{y}} * \mathbf{Y}-c_{\mathrm{u}} * \mathbf{U}-c_{\mathrm{z}} * \mathbf{Z} .
$$

Here $\mathbf{P}$ - profit, $c_{y}$ - output prices, $c_{u}$ - prices of managed inputs, $\mathrm{c}_{\mathrm{z}}-$ pollution losses or pollution tax if applicable.

In the model of linear programming for the optimization of regional agrarian sector economics the biological, physical and economical knowledge is integrated. In such a model the mathematical programming algorithms help to determine input combinations, which are the best suitable under certain conditions. The decisions "if - then" are described by rules.

Having joined the models in the base of models convenient conditions can be created for the user to make use of the system of models, and, according to the need, to select the necessary model or group of models. Aggregated simulation results of the integrated model system can be applied in land use analysis, regional rural development policy formation. Several types of systematic analysis of regional agrarian sector can be performed: analysis of solutions, based on simulation of biological-physical processes; analysis of economical solutions, based on production functions; dynamic simulation of production processes; simulation, based on the investigation of possible alternative management impacts. The optimal development can be selected in modelling possible input output combinations, and evaluating the valid limitations by the method of linear programming. The methods of artificial intellect suggest heuristic methods of purposeful search for solutions. Solution support systems, based on artificial intelligence technologies are increasingly important.

Modelling of regional agrarian sector activity facilitates better understanding of the activity processes, problems and participants. Integrated models system helps to evaluate regional policy decisions, the dependence of agricultural production efficiency and final results on the decisions made, resistance to internal and external hindrances. The simulation model, which enables to check the alternative activity strategies, is convenient in the work of regional advisory service as a measure for decision making. Agrarian sector activity model is structural description of knowledge, preconditions, data, which is necessary in creation of agrarian sector information system.

\section{Conclusions}

The performed investigation of Lithuanian regional agrarian sector development strategies formation shows that regional development modelling technologies that are widely developed in foreign countries are insufficiently evaluated and applied in Lithuania. At present the quantitative and qualitative instrumental measures, which could be used by those who form regional rural development strategy in their work, are in need.

The method of integrated modelling is suggested to be used in the investigation of regional agrarian sector development possibilities. The presented methodic of integrated modelling of region and farm level processes provides creation of regional agrarian sector model, simulation of biological and production processes, optimization of the created development plan by the method of linear programming. The integrated models system helps to evaluate the regional policy solutions, the dependence of agricultural production efficiency and final results on the decisions made, resistance to internal and external hindrances. 


\section{References}

1. H. Pranevičius, I. Kriščiukaitienè, A. Kuodys. Lietuvos žemès ūkio valdymo konceptualinis modelis. Informacinès technologijos 98. Kaunas: Technologija, 1998, p. 280-284 (in Lthuanian).

2. Rita Bagdzevičienè, Justinas Rimas, Algimantas Venckus. Regionų ekonomikos plètros strategija. Regionų plètra - 2002. Kaunas: Technologija, 2002, p. 30-35 (in Lthuanian).

3. Jonas Čaplikas. Mažiau palankių ūkininkauti vietovių atrankos kriterijų parinkimas. Regionų plètra - 2002. Kaunas: Technologija, 2002, p. 55-61 (in Lthuanian).

4. Clifford R. Jurgens. Strategic planning for sustainable rural development. In: Landscape and Urban Planning. Vol 27, No 2-4, December 1993, p. 253-258.

5. Andrew Farrow and Manuel Winograd. Land use modelling at the regional scale: an input to rural sustainability I ndicators for Central America. In: Agriculture, Ecosystems \& Environment. Vol 85, No 1-3, June 2001, p. 249-268.

6. D. Deybe. Can agricultural sector models be a tool for policy analysis? An application for the case of Burkina Faso. In: Agricultural Systems. Vol 58, No 3, November 1998, p. 367-380.

7. Inderjit Singh, Choong Yong Ahn. A dynamic multi-commodity model of the agricultural sector. In: European Economic Review. Vol 11, No 2, August 1978, p. 155179.

8. Stuart H. Gage, Manuel Colunga-Garcia, John J. Helly, Gene R. Safir and Arif Momin. Structural design for management and visualization of information for simulation models applied to a regional scale. In: Computers and Electronics in Agriculture. Vol 33, No 1, December 2001, p. 77-84.

9. O. Howells, G. Edwards-Jones, O. Morgan. Ecozone II: a decision support system for aiding environmental impact a ssessments in agriculture and rural development projects in developing countries. In: Computers and Electronics in Agriculture. Vol 20, No 2, July 1998, p. 145-164.

10. Keith B. Matthews, Alan R. Sibbald and Susan Craw. Implementation of a spatial decision support system for rural 1 and use planning: integrating geographic in- formation system and environmental models with search and optimisation algorithms. In: Computers and Electronics in Agriculture. Vol 23, No 1, June 1999, p. 926.

11. Sheila Bliss Duffy, Michael S. Corson and W. E. Grant. Simulating land-use decisions in the La Amistad Biosphere Reserve buffer zone in Costa Rica and Panama. In: Ecological Modelling. Vol 140, No 1-2, 30 May 2001, p. 9-29.

12. C. F. Palmer. Systems analysis and model building techniques in rural development In: International Journal of Project Management. Vol 2, No 4, November 1984, p. 232-239.

13. P. Geoffrey Allen. Economic forecasting in agriculture In: International Journal of Forecasting. Vol 10, No 1, June 1994, p. 81-135.

14. Ashok Parikh. An econometric model of the agricultural sector of the Indian economy, In: Journal of Policy Modeling. Vol 4, No 3, November 1982, p. 395-411.

15. J. J. Glen and R. Tipper. A mathematical programming model for improvement planning in a semi-subsistence farm. In: Agricultural Systems. Vol 70, No 1, October 2001, p. 295-317.

16. Siegfried Bauer, Haluk Kasnakoglu. Non-linear programming models for sector and policy analysis, Experiences with the Turkish agricultural sector model. In: Economic Modelling. Vol 7, No 3, July 1990, p. 275-290.

17. Sushil Pandey and J. Brian Hardaker. The Role of Modelling in the Quest for Sustainable Farming Systems. In: Agricultural Systems. Vol 47, No 4, 1995, p. 439-450.

18. H. Pranevičius, A. Kurlavičius. Žemès ūkio gamybos valdymo agregatinis modelis. In: Informacinès technologijos 2002. Kaunas: Technologija, 2002, p. 235-239 (in Lthuanian).

19. G. Van Huylenbroeck, G. Jacobs, P. Vanrolleghem. A simulation model to evaluate the impact of environmental programmes on dairy farms, In: International Transactions in Operational Research. Vol 7, No 2, March 2000, p. 171-183.

20. Algimantas Kurlavičius. Žemès ūkio įmonès gamybos struktūros optimizavimo sistema. Vagos. Lžū universitetas. Mokslo darbai 56 (9). Akademija, 2002, p. 95-99 (in Lthuanian). 